\title{
Enhancing DNA electrotransformation efficiency in Escherichia coli DH10B electrocompetent cells
}

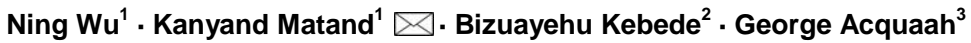 \\ Sonya Williams ${ }^{4}$ \\ 1 Center for Biotechnology Research and Education, Langston University, Langston, OK 73050, USA \\ 2 Department of Chemistry, School of Arts and Sciences, Langston University, Langston, OK 73050, USA \\ 3 Department of Agriculture and Natural Resources, School of Agriculture \& Applied Sciences, Langston \\ University, Langston, OK 73050, USA \\ 4 Departments of Biology, Langston University, Langston, OK 73050, USA \\ $\triangle$ Corresponding author: lu3836@yahoo.com \\ Received December 11, 2009 / Accepted June 3, 2010 \\ Published online: September 15, 2010 \\ (C) 2010 by Pontificia Universidad Católica de Valparaíso, Chile
}

Abstract Electrotransformation also known as electroporation is the most reliable and efficient tool for plasmid DNA uptake. Electrotransformation efficiency is function of many factors which include (1) number of cell washes prior to electroporation, (2) electroporation cell number, (3) electroporation DNA amount, and (4) cell growth phase. Those factors have limitedly been concomitantly investigated in $E$. coli DH10B strain. This study is aimed to explore above key factors to define the optimal conditions for high electrotransformation efficiency. The results showed that electrotransformation efficiency of $E$. coli DH1OB was enhanced to $1.5 \times 10^{9} \mathrm{cfu} / \mu \mathrm{g}$ by washing cells three times with $15 \mathrm{ml}$ of $10 \%$ glycerol. This washed off extra salts from cell suspension and enhanced electrotransformation by preventing arcing and enhancing cell resistance while ensuring minimal level of conductivity. Early exponential phase at $0.15 \mathrm{OD}_{600}$ was the best growth phase for enhancing electrotransformation of $E$. coli $\mathrm{DH} 10 \mathrm{~B}$. The results also showed that higher electrotransformation efficiency was similarly achieved when $0.5 \times 10^{10}$ and $0.6 \times 10^{10}$ cell numbers were electroporated with DNA amount ranging from 10 to $40 \mathrm{pg}$. This study confirmed the optimal conditions for electro competent cell preparation and plasmid DNA electrotransformation, which can result highest transformation efficiency.

Keywords: cell competency, DNA, E. coli DH10B, electroporation

\section{INTRODUCTION}

Electroporation is an ionic restricted physical process that requires a cell suspension of high resistance and very low conductivity for a high degree of success (Dower et al. 1988). It is preferred over the chemical method for transferring exogenous DNA into bacteria, because of its (1) high transformation efficiency that is suitable for regular 
plasmid, ligated cDNA, and genomic DNA transformation; (2) suitability of using less transforming DNA amount for high transformation efficiency, which is beneficial for rare and/or hard-to-obtain gene DNA; and (3) transformation irreversibility compared to chemical transformation method (Kurien and Scofield, 1995). However, this method has some limitations. For instance, during conventional electrocompetent cell preparation, extra-sodium chloride is normally used as a major ion source in the medium (about 1\% in LB medium). This practice can dramatically reduce the electrotransformation efficiency and cause arcing. Therefore, all the salts from the cell suspension must be removed by extensive washing. Although low salts buffer is usually used to remove these salts, the use of a nonionic buffer such as glycerol would be more preferable. Buffers such as water (Enderle and Farwell, 1998; Papagianni et al. 2007), water and glycerol (Sheng et al. 1995; Sharma and Schimke, 1996), or salts buffer and glycerol have also been widely used (Dower et al. 1988). However, glycerol is seldom used alone as a buffer (Dorella et al. 2006). There is a need for alternative methods of cell desalination because current protocols for salt removal produce variable results that are difficult to reproduce. Further, extensive washing and resuspension steps can result in contamination and lower electroporation efficiency due to lower cell viability (Sharma and Schimke, 1996).

Generally, the conventional electrocompetent cell preparation is a relatively timeconsuming process that involves several rounds of extensive washes and centrifugation. More importantly, the protocol results in significantly low transformation efficiency, compared to what is achieved by commercial companies (Enderle and Farwell, 1998; Tu et al. 2005). Thus, commercially prepared competent cells, even though very expensive, have become the preferred source of such material in conventional research and teaching laboratories. Further, standardized protocols on different $E$. coli strains have been reported (Chung et al. 1989; Tu et al. 2005). Despite the fact that $E$. coli $\mathrm{DH} 10 \mathrm{~B}$ strain is commonly used in research (Narayanan et al. 1999; Poirel et al. 2005), only limited transformation efficiency investigations involving this organism have been reported (Ceremonie et al. 2004). Further, only very limited if not none of the reports has focused on enhancing electrotransformation efficiency by simultaneously varying electroporation cell number and frequency, DNA amount, cell desalination, and cell growth phase, as is reported in this study. Such information is essential because electrotransformation efficiency is species- and strain-dependent (Chung et al. 1989; Sheng et al. 1995; Enderle and Farwell, 1998; Tu et al. 2005). Therefore, it is critical to standardize individual protocol for transformation efficiency improvement on this strain.

In this study, we report the results of an investigation that focused on all those parameters for standardizing electrotransformation protocol for $E$. coli strain $\mathrm{DH} 10 \mathrm{~B}$, which has resulted in consistently enhanced efficiency. The unique feature of this investigation is that higher electrotransformation efficiency was achieved solely by adjusting related variables within the existing conventional protocol, without considering new parameters. The modifications made are simple, efficient, costeffective, and most of all consistently reproducible in both conventional research and teaching laboratories. 


\section{MATERIALS AND METHODS}

\section{Electrocompetent cell preparation}

Escherichia coli strain DH10B (genotype: F- mcrA $\Delta$ ( mrr-hsdRMS-mcrBC)

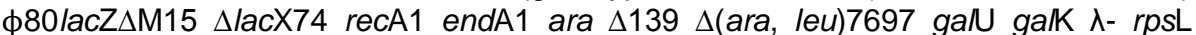
$\left(\mathrm{Str}^{\mathrm{R}}\right.$ ) nupG) electrocompetent cells (ELECTROMAX DH10B CELL, Cat. No. 18290015) and pUC19 plasmid DNA were purchased from INVITROGEN (Carlsbad, CA, USA). The bacterium was first streaked on LB agar plate and a single colony picked and grown in $10 \mathrm{ml} \mathrm{LB}$ medium at $37^{\circ} \mathrm{C}$, shaking overnight. Two and half millilitre bacterial culture was transferred to $500 \mathrm{ml}$ of LB medium and incubated at $37^{\circ} \mathrm{C}$ with vigorous shaking at $300 \mathrm{rpm}$ till the cell density reached designated absorbance at $600 \mathrm{~nm}\left(\mathrm{~A}_{600}\right)$. Then, the cells were collected by centrifugation and subjected to $15 \mathrm{ml}$ of $10 \%$ ice-cold glycerol wash. Washed cells were resuspended in $10 \%$ ice-cold glycerol and distributed into $100 \mu \mathrm{l}$ aliquots with proper number of cells calculated according to the formula $1 \mathrm{OD}_{600}=5 \times 10^{8} \mathrm{cells} / \mathrm{ml}$ provided by the instruction manual for SMARTSPEC 3000 Spectrophotometer (BIO-RAD LABORATORIES, Hercules, CA, USA). The cell aliquots were either directly applied for electroporation of pUC19 plasmid DNA or quickly frozen by dry-ice/ethanol and stored in $-80^{\circ} \mathrm{C}$ for future use.

\section{Electroporation variables assays}

A series of electroporation assays was performed in triplicate format by using MicroPulser Electroporator (BIO-RAD LABORATORIES, Hercules, CA, USA) to optimize electrotransformation efficiency of $E$. coli DH10B cells by optimizing different electroporation parameters including cell growth harvest point, cell wash times, cell number, and transforming DNA amount. Cells were harvested at three different $\mathrm{OD}_{600}$ growing points including $0.15,0.25$, and 0.45 , which represented early, mid and late exponential (log) phase stages. Harvested cells were desalinated by washing once or three times with $15 \mathrm{ml}$ of $10 \%$ ice-cold glycerol to determine the optimal wash times required to remove salts for enhanced maximum transformation efficiency. Washed cells were diluted and aliquoted to the final concentration of $1,0.9,0.7,0.6,0.5$, and $0.2\left(\times 10^{10}\right)$ cells per $100 \mu$ l solutions, also to determine the optimal cell number that could yield the best electrotransformation efficiency. Lastly, those cell samples were exposed to different amounts of transforming DNA (dissolved in pure water) to determine the optimal cell number that will take up the maximum exogenous DNA when exposed to electrical shocks. Transforming DNA amounts tested included 10, 20,40 , and $80 \mathrm{pg}$. All samples were electroporated in a 0.2-cm-gap cuvette (BIORAD, Hercules, CA) at $12.5 \mathrm{KV} / \mathrm{cm}$ (field strength), $200 \Omega$ (resistor), and $25 \mu \mathrm{F}$ (capacitor).

\section{RESULTS AND DISCUSSION}

\section{Enhancement of transformation efficiency via cell growth phase}

There are three key steps in the introduction of exogenous DNA into $E$. coli: (1) the growth of bacteria, (2) the preparation of cell competency for DNA uptake and (3) the transformation of the cells with the DNA. The exponential phase is the most critical cell growth phase recommended to facilitate maximum exogenous DNA uptake in 

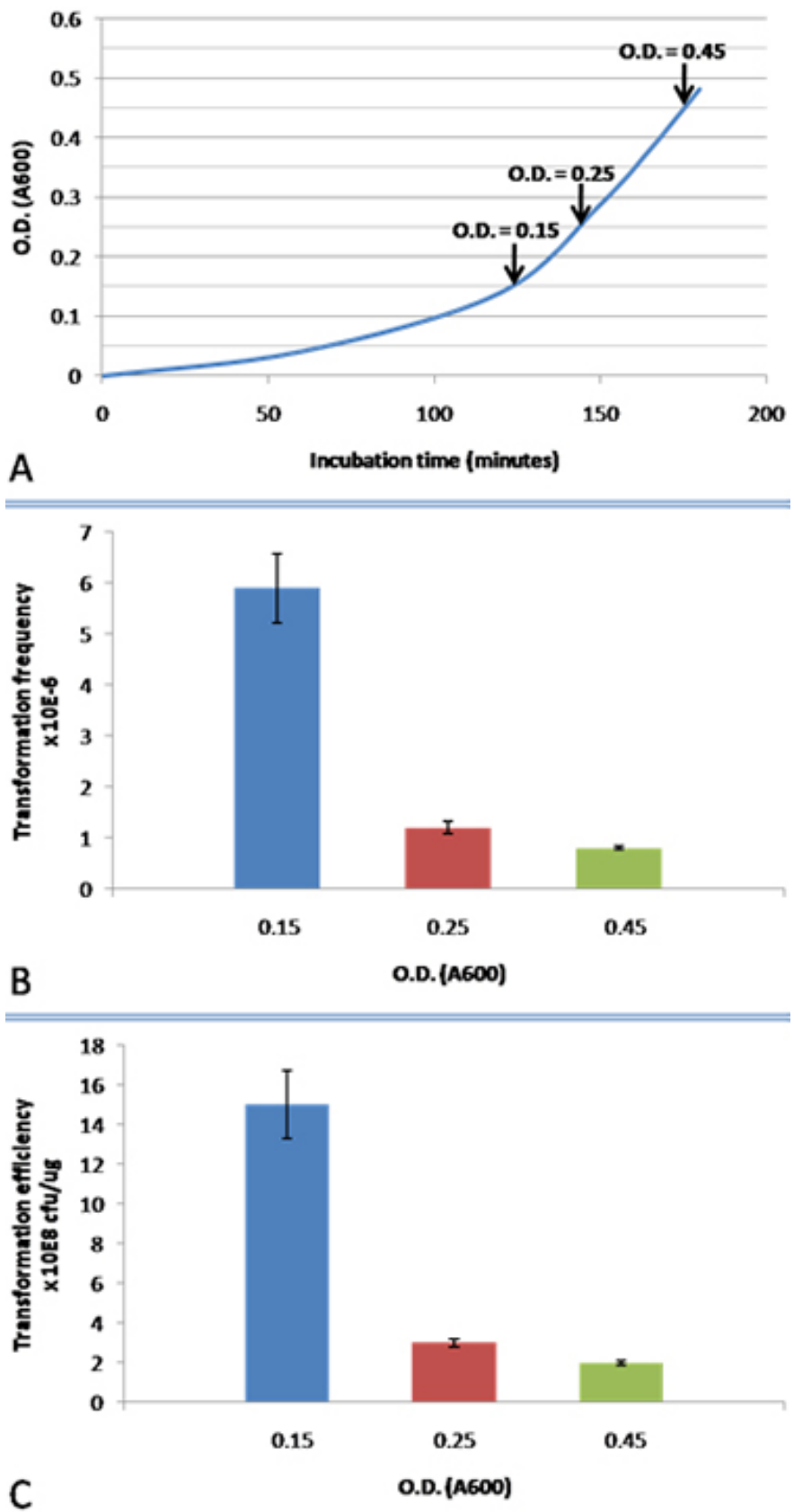

Fig. 1 Effect of cell growth phase on transformation frequency and efficiency. 
it is dependent upon the strain, construct, chemical composition of the medium and conditions of incubation (Dower et al. 1988; Tu et al. 2005). In this study, E. coli $\mathrm{DH} 10 \mathrm{~B}$ cells that were used and grown in LB medium reached exponential phase within 2 hrs of incubation, and three cell $\mathrm{OD}_{600}$ harvest points, $0.15,0.25$ and 0.45 were determined as representatives of early, middle, and late exponential phase were stages, respectively (Figure 1a). Observations made at those three points support the hypothesis that cell electrotransformation frequency is inversely proportional to cell population size (Figure 1b). Accordingly, early log phase stage yielded higher frequency of cells that were transformed than mid and late log phase stages. Similarly, transformation efficiency was also inversely proportional to cell population size (Figure 1c). The greatest $1.5 \times 10^{9}$ colony forming units per microgram transforming DNA (cfu/ $\mu \mathrm{g}$ ) was observed in cells harvested at the smallest $\mathrm{OD}_{600}$, 0.15 , compared to $3.0 \times 10^{8}$ and $2.0 \times 10^{8} \mathrm{cfu} / \mu \mathrm{g}$ from cells harvested at the last two $\mathrm{OD}_{600}$ points, 0.25 and 0.45 , respectively (Figure $1 \mathrm{c}$ ). This reinforces the significance

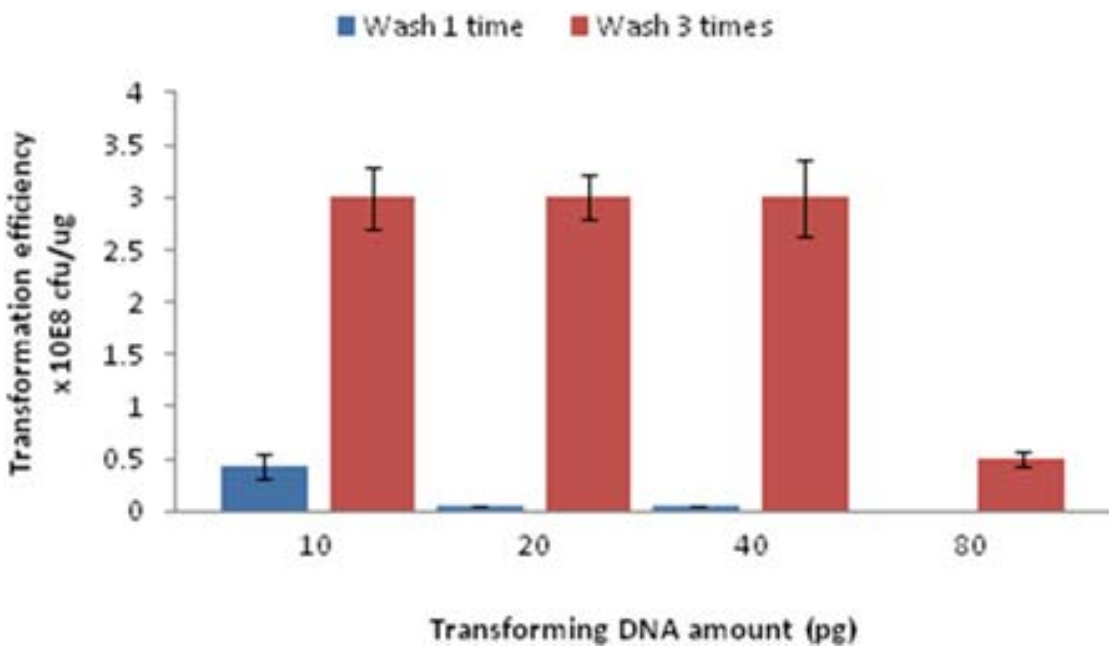

Fig. 2 Effect of cell wash time and transforming DNA amount on transformation efficiency.

of growth phase in general and early log phase stages in particular, in routine lab applications. It also supports the fact that the adjustment of this variable alone can maximize $E$. coli cell transformation efficiency, to a competitively high level of commercial production. The current normal range of industrial bacterial cell transformation efficiency is $10^{9}-10^{10} \mathrm{cfu} / \mathrm{\mu g}$. It has also been reported that late cell growth phases can yield transformation efficiencies as high as $10^{5}-10^{7}$ transformants per microgram DNA (Chung et al. 1989; Ceremonie et al. 2004). This, coupled with the fact that, generally, early log phase stage is characterized by lower cell density compared to late log phase stages, leads us to recommend an $\mathrm{OD}_{600}$ range of 0.20 0.25 , to ensure overall higher number of transformants.

\section{Enhancement of transformation efficiency through glycerol cell desalination}

During competent cell preparation for electroporation, it is essential to extensively wash cells to remove residual culture medium and reduce the ionic strength of the cell 
suspension while ensuring its high resistance and very low conductivity (Dower et al. 1988). It is necessary to avoid the interference of salts that could reduce electrotransformation efficiency and cause arcing. During this study, we assessed the efficacy of one- and three-time $15 \mathrm{ml}-10 \%$-ice-cold glycerol washes of harvested cells in reducing the ionic strength of the cell suspension and removing residual culture medium prior to aliquoting. The investigation yielded results that showed a significant and direct link between increased number of washes and cell transformation efficiency. We observed that, with three-time washes cell transformation efficiency was increased by 7.5 to 60 folds compared to the cells that were washed only once (Figure 2). The enhancing of cell transformation efficiency was consistent, irrespective of the transforming DNA amount used. However, under the conditions of this study any increase in number of washes over three times did not show noticeable increase in electrotransformation efficiency (data not shown). It suggests that three-time washes were sufficient in reducing salts to the acceptable lower level ionic strength of the suspension for low conductivity (Dower et al. 1988), which ensures high resistance required for the electroporation medium (Sharma and Schimke, 1996). The results reinforce common knowledge that the removal of salts prior to DNA transfer is an essential step in electrocompetent cell preparation.

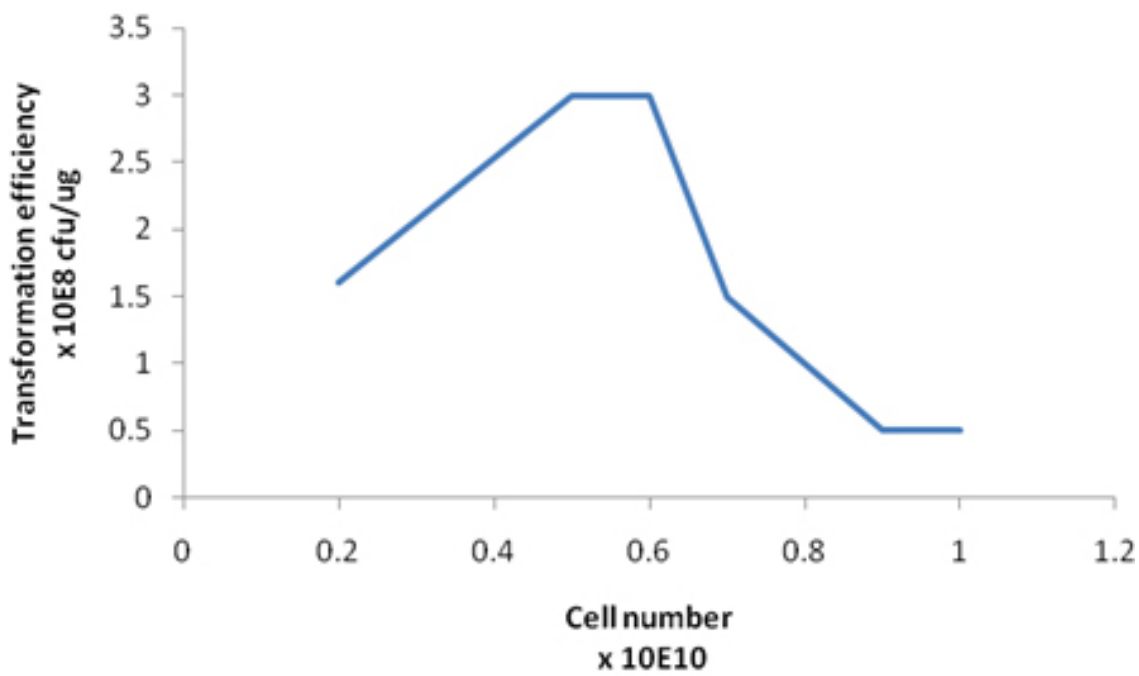

Fig. 3 Effect of electroporation cell number on transformation efficiency.

\section{Enhancing transformation efficiency through electroporation cell number}

Cell number in an electroporation sample is another essential parameter that can be manipulated to enhance cell transformation efficiency. We investigated the impact of a wide range of cell number, $0.2-1\left(\times 10^{10}\right)$, on cell transformation efficiency. The results showed a direct link between electroporation cell number and transformation efficiency. The highest transformation efficiency peak $\left(3 \times 10^{8} \mathrm{cfu} / \mu \mathrm{g}\right)$ was observed when $0.5 \times 10^{10}$ and $0.6 \times 10^{10}$ cell numbers were electroporated, respectively. However, transformation efficiency decreased when electroporation involved the number of cells beyond $0.6 \times 10^{10}$ (Figure 3). Although there is no clear explanation 
for this outcome, we suspect a limited interaction between DNA molecules and bacterial cells could be responsible. This, because the fixed number of transformant molecules in invariable sample DNA amount might increasingly interact limitedly with the maximum electroporation bacterial cells as their number increases. Much lower transformation efficiency $\left(8.5 \times 10^{7} \mathrm{cfu} / \mu \mathrm{g}\right)$ has also been reported in $E$. coli $\mathrm{DH} 10 \mathrm{~B}$ (Ceremonie et al. 2004). The influence of cell number on cell transformation efficiency has previously been investigated on another strain of $E$. coli (Chung et al. 1989). In that study, Chung et al. (1989) investigated three levels of cell number (1x,10x and $100 \mathrm{x}$ original cell number increase). The results showed the $10 \mathrm{x}$ increase in cell number yielded the highest number of transformants $\left(10.08 \times 10^{7} \mathrm{cfu} / \mu \mathrm{g}\right)$. The increase in cell number beyond this point resulted in a dramatic decrease in cell transformation efficiency. When similar studies were conducted in other species such as Rhizobium leguminosarum (Garg et al. 1999), a continuous increase in cell transformation was observed in response to a continuous increase in electroporation cell number.

\section{Using DNA amount to enhance cell transformation efficiency}

Transformation efficiency is the number of cells transformed out of one microgram DNA. It has been studied in other bacterial species such as Corynebacterium pseudotuberculosis (Dorella et al. 2006). The results showed there was an inversely proportional relation between the quantity of transforming plasmid DNA and transformation efficiency (Dorella et al. 2006). Different amounts of pUC19 DNA (10$80 \mathrm{pg}$ ) were used to transform $0.5 \times 10^{10}$ electrocompetent cells. The results showed there was no difference in transformation efficiency for DNA amount ranging from 10 to $40 \mathrm{pg}$, which caused the highest transformation efficiency of $3 \times 10^{8} \mathrm{cfu} / \mu \mathrm{gg}$ (Figure 2). However, when the amount of transforming DNA was increased beyond $40 \mathrm{pg}$, transformation efficiency decreased significantly, by six folds. Under these experimental conditions, using plasmid DNA as little as $10 \mathrm{pg}$ will ensure the maximum transformation efficiency, which could maximize efficient use of limited amount of rare clones or hard to obtain gene DNA and reduce the cost. Different bacterial species or strains respond differently when subjected to variable amounts of transforming DNA for electroporation. Within other E. coli strains, Chung et al. (1989) showed numerical increase in transformation efficiency when it was subjected to transforming DNA amounts ranging from $10 \mathrm{pg}$ to $1 \mathrm{ng}$. However, the increases of DNA amount were not statistically significant. Their study showed that when transforming DNA amount was increased beyond $1 \mathrm{ng}$, the transformation efficiency dropped. More importantly, their study showed a numeric transformation efficiency increase, from $6.20 \times 10^{7}$ to $7.33 \times 10^{7} \mathrm{cfu} / \mu \mathrm{g}$, when transforming DNA amount was increased in E. coli $\mathrm{DH} 10 \mathrm{~B}$, from $10 \mathrm{pg}$ to $100 \mathrm{pg}$. Considering similar range of transforming DNA amount, we observed a dramatic decrease in transformation efficiency when $80 \mathrm{pg}$ and greater amounts were tested. The maximum transformation efficiency in this study resulting from the tested DNA amount variable, $3 \times 10^{8} \mathrm{cfu} / \mu \mathrm{g}$, was also much higher than their observed value of $7.33 \times 10^{7} \mathrm{cfu} / \mu \mathrm{g}$. Another strain of E. coli, NEB 5-alpha, that was studied showed an increase in transformation efficiency to the maximum of $\sim 2.6 \times 10^{10}$ transformants per microgram DNA, when it was exposed to $100 \mathrm{pg}$ transforming DNA.

Finally, this study supports previous finding that cell number, cell desalination, DNA amount, and cell growth phase are essential variables that can efficiently be manipulated independently to enhance cell electrotransformation efficiency in $E$. coli, $\mathrm{DH} 10 \mathrm{~B}$ strain. Early log phase, at about $0.15 \mathrm{OD}_{600}$, is the best target growth phase 
stage to sample cells potential of yielding the highest electrotransformation efficiency

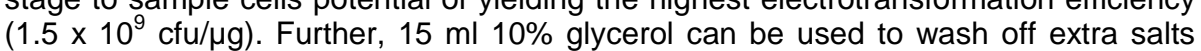
from cell suspension and enhance electrotransformation by preventing arcing and enhancing cell resistance while ensuring minimal level of conductivity. The optimization of this variable alone can generate at least $3 \times 10^{8} \mathrm{cfu} / \mu \mathrm{g}$. Similar higher electrotransformation efficiency $\left(3 \times 10^{8} \mathrm{cfu} / \mu \mathrm{g}\right)$ can also be achieved when electroporation cells are exposed to transforming DNA amount ranging from 10 to 40 pg. The investigation reinforces the notion that even limited size and/or low-budget molecular biology laboratories have equal opportunities for routine preparation of electrocompetent cells with very high transformation efficiency ranging from $10^{8}$ to $10^{9}$ $\mathrm{cfu} / \mu \mathrm{g}$ by manipulating the level of glycerol alone. This range might be extended to $10^{10}$ when these optimized variables are applied altogether.

\section{ACKNOWLEDGMENTS}

The authors are grateful to Wondwessen Kebede, an undergraduate student in the Department of Biology, for his contribution during the conduct of this study.

Financial support: This study was partially funded by USDA/CSREES and NSF/SURESTEP Program.

\section{REFERENCES}

CÉRÉMONIE, Hélène; BURET, François; SIMONET, Pascal and VOGEL, Timothy M. Isolation of lightning-competent soil bacteria. Applied and Environmental Microbiology, October 2004, vol. 70, no. 10, p. 6342-6346. [CrossRef]

CHUNG, C.T.; NIEMELA, S.L. and MILLER, R.H. One-step preparation of competent Escherichia coli: transformation and storage of bacterial cells in the same solution. Proceedings of the National Academy of Sciences of the United States of America, April 1989, vol. 86, no. 7, p. 2172-2175. [CrossRef]

DORELLA, F.A.; ESTEVAM, E.M.; CARDOSO, P.G.; SAVASSI, B.M.; OLIVEIRA, S.C.; AZEVEDO, V. and MIYOSHI, A. An improved protocol for electrotransformation of Corynebacterium pseudotuberculosis. Veterinary Microbiology, May 2006, vol. 114, no. 34, p. 298-303. [CrossRef]

DOWER, William J.; MILLER, Jeff F. and RAGSDALE, Charles W. High efficiency transformation of $E$. coli by high voltage electroporation. Nucleic Acids Research, 1988, vol. 16, no. 13, p. 6127-6145. [CrossRef]

ENDERLE, Patrick J. and FARWELL, Mary A. Electroporation of freshly plated Escherichia coli and Pseudomonas aeruginosa cells. Biotechniques, December 1998, vol. 25, no. 6, p. 954-958.

GARG, Bindu; DOGRA, Romesh C. and SHARMA, Parveen K. High-efficiency transportation of Rhizobium leguminosarum by electroporation. Applied and Environmental Microbiology, June 1999, vol. 65, no. 6, p. 2802-2804.

KURIEN, Biji T. and SCOFIELD, R. Hal. Polyethylene glycol-mediated bacterial colony transformation. Biotechniques, June 1995, vol. 18, no. 6, p. 1023-1026.

NARAYANAN, K.; WILLIAMSON, R.; ZHANG, Y.; STEWART, A.F. and IOANNOU, P.A. Efficient and precise engineering of a $200 \mathrm{~kb}$ beta-globin human/bacterial artificial chromosome in $E$. coli $D H 1 O B$ using an inducible homologous recombination system. Gene Therapy, March 1999, vol. 6, no. 3, p. 442-447.

PAPAGIANNI, Maria; AVRAMIDIS, Nicholaos and FILIOUSSIS, George. High efficiency electrotransformation of Lactococcus lactis spp. lactis cells pretreated with lithium acetate and dithiothreitol. BMC Biotechnology, March 2007, vol. 7, no. 15. [CrossRef] 
POIREL, L.; HERITIER, C. and NORDMANN, P. Genetic and biochemical characterization of the chromosome-encoded class B $\beta$-lactamases from Shewanella livingstonensis (SLB-1) and Shewanella frigidimarina (SFB-1). Journal Antimicrobial Chemotherapy, May 2005, vol. 55, no. 5, p. 680-685. [CrossRef]

SHARMA, Rakesh C. and SCHIMKE, Robert T. Preparation of electrocompetent E. coli using salt-free growth medium. Biotechniques, January 1996, vol. 20, no. 1, p. 42-44.

SHENG, Yuling; MANCINO, Valeria and BIRREN, Bruce. Transformation of Escherichia coli with large DNA molecules by electroporation. Nucleic Acids Research, June 1995, vol. 23, no. 11, p. 1990-1996. [CrossRef]

TU, Zhiming; HE, Guangyuan; LI, Kexiu X.; CHEN, Mingjie J.; CHANG, Junli; CHEN, Lin; YAO, Qing; LIU, Dongping; YE, Huan; SHI, Jiantao and WU, Xuqian. An improved system for competent cell preparation and high efficiency plasmid transformation using different Escherichia coli strains. Electronic Journal of Biotechnology, April 2005, vol. 8, no. 1. [CrossRef]

\section{How to cite this article:}

WU, N.; MATAND, K.; KEBEDE, B.; ACQUAAH, G. and WILLIAMS, S. Enhancing DNA electrotransformation efficiency in Escherichia coli DH10B electrocompetent cells. Electronic Journal of Biotechnology, September 2010, vol. 13, no. 5. http://dx.doi.org/10.2225/vol13-issue5-fulltext-11 